\title{
OPTIMIZATION OF SANDING PARAMETERS USING RESPONSE SURFACE METHODOLOGY
}

\author{
Ender Hazir', Kücük Hüseyin Koc², Salim Hiziroglü ${ }^{3, \$}$
}

\begin{abstract}
The main objective of this work is to develop a mathematical model to evaluate optimum sanding conditions of Europen black pine (Pinus nigra). Samples were sanded using different of grit size, feed rate, cutting speed and depth of cut. Average surface roughness $\left(\mathrm{R}_{\mathrm{a}}\right)$ values of each type of specimens were measured employing a stylus type of equipment. Interaction between sanding parameters and surface roughness of the species were analyzed using Minitab software and response surface methodology. Based on the findings in the work feed rate, cutting speed, grit size and depth of cut values of $5,39 \mathrm{~m} / \mathrm{min}, 19,75 \mathrm{~m} / \mathrm{sec}, 220$ (grit size) and $9 \mathrm{~mm}$ were determined as optimum sanding conditions.
\end{abstract}

Keywords: Cutting speed, European black pine, feed rate, statistical techniques, surface roughness, wood machining, wood sanding process.

\section{INTRODUCTION}

Sanding is one of the most common processes in the woodworking industry. This process effects surface roughness and surface coating performance (Gurau et al. 2015, Hiziroglu et al. 2014, Kılıç et al. 2006, Magoss 2015, Vitosyte et al. 2012). The surface roughness is significant factor influencing overall manufacturing process such as bonding quality, painting properties and processing time. However wood sanding operation depends on to several factors such as anatomical structure, moisture, hardness, density, annual ring variation, cell structure early wood latewood latewood ratio (Hiziroglu et al. 2013, Ratnasingman and Scholz 2006). Additionally, wide belt sanding machine is commonly used for furniture industry. The machine conditions including grit size, feed rate and pressure effected the surface quality (Ozdemir and Hiziroglu 2007, Moura and Hernandez 2006, Gurau et al. 2013). The sanding process is a complex process due to the anisotropic and heterogeneous nature of the wood material (Saloni et al. 2010). Sanding plays a significant role on different aspects of furniture manufacturing such as finishing, coating as well as surface quality (Landry and Blanchet 2012, Hernández and Cool 2008, Scrinzi et al. 2011). Therefore, it is very difficult to optimize different process so that a model can be applied for that purpose. Selection of optimum machining parameters is necessary to provide better surface quality and process planning. Design of experiment is an important step determining interaction between the parameters considered in this study. Advanced experimental design is required to reduce the number of experiment. Design of experiment (DOE) methodology is powerful techniques to reduce the number of replicates. Central Composite Design (CCD), Taguchi and Box-Bohen (BBD) design have been widely used in engineering applications (Herrera et al. 2015, Jacob and Banerjee 2016, López et al. 2016). These techniques are ideal to have an efficient and effective the experimental design with lower cost. A study was carried out by Carrano et al. (2002)

${ }^{1}$ Faculty of Forestry, Department of Forest Industry Engineering, Istanbul University, Istanbul, Turkey. ender.hazir@istanbul. edu.tr

${ }^{2}$ Faculty of Forestry, Department of Forest Industry Engineering, Istanbul University, Istanbul, Turkey. hkoc@istanbul.edu.tr ${ }^{3}$ Department of Natural Resources, Ecology and Management, Oklahoma State University, Stillwater, USA.

"Corresponding author: salim.hiziroglu@okstate.edu

Received: 06.11.2016 Accepted: 10.06.2017 
investigated sanding process of hard maple, white oak and eastern white pine as function of spindle speed, feed rate, depth of cut, grit size, tooling resilience and grain orientation. The results showed the grit size, tooling resilience and grain orientation to be significant for all species. Feed rate was found as a significant factor for white oak and eastern white pine. Aslan et al. (2008) also evaluated influence of sanding direction, grit size and number of sanding blades in overall surface roughness of Toros cedar (Cedrus libani). According to the results of this study, it was determined that the cutting direction and finishing techniques affected the surface roughness of the specimens. The samples had smoother surfaces with increasing the grit number of the abrasive increases. Sulaiman et al. (2009) investigated the effect of sanding parameters on the surface roughness of Rubberwood (Hevea brasilinsis). Results showed the samples had better surfaces quality with increasing the grit number of abrasive. Varanda et al. (2010) reported that sanding process parameters such as belt speed and grit sizes were effective on the surface quality of Eucalyptus grandis wood. It was found that smaller abrasive grains revealed better surface roughness of the samples. The optimum surface roughness value of sanded kembang semangkok (Scaphium spp.), red oak (Quercus spp.) and spruce (Picea spp.) studied by Tan et al. (2012). Samples were sanded using different grit size and feed rate. Influence of these parameters were examined by RSM and ANOVA. Effects of grit size, wood types and feed rate were found significant factors. Sanding processing parameters were investigated and their effects on wood surface roughness were determined in various past studies. However, there is little as no information determining the optimum processing parameters for furniture industries. In this study, in contrast to these reported in literature a mathematical model was developed based on CCFC design and RSM method for solving the wood surface roughness problem.

\section{MATERIAL AND METHODS}

European black pine (Pinus nigra Arnold) species are extensively used in the furniture industry and they were selected for the study. The samples were prepared with the dimension of $200 \mathrm{~mm} \times 100$ $\mathrm{mm}$ x $30 \mathrm{~mm}$ for each test. Density level of Black pine was measured randomly using 31 samples. Each sample was weighed and its dimensions were measured at an accuracy level of $0,1 \mathrm{~g}$ and $0,01 \mathrm{~mm}$ respectively. Samples were conditioned in a climate room having a temperature of $20^{\circ} \mathrm{C}$ and relative humidity of $65 \%$ until they reach a moisture content of $9 \pm 1 \%$. The density of Black pine was measured as $680 \mathrm{~kg} / \mathrm{m}^{3}$.

\section{Machining conditions}

The samples were processed with wide-belt sanding machine in an industrial environment for this purpose. The sanding treatment was wide belt sander equipped with open coat aluminum oxide abrasive paper. The review of literature indicates that the following four machining parameters are the most widespread among the researcher and operator to control the sanding process: feed rate (f, $\mathrm{m} / \mathrm{min}$ ), cutting speed (s, m/sec) grit size (p) and depth of cut (d). In this work, these were selected as design factors while other parameters such as belt tension of $3 \mathrm{~kg} / \mathrm{cm}^{2}$ and aluminum oxide sander paper type were taken as fixed values. The samples with parallel orientations from each species were prepared using sanding machine. Roughness measurement device is a stylus-based portable profilometer that is Sutronic- 25 type equipment. Diamond stylus with a $5 \mu$ m radius and $90^{\circ}$ of tip angle was employed for roughness measurement. According to ISO 4287, there are two accepted roughness parameters, namely average roughness $\left(R_{\mathrm{a}}\right)$ and mean peak to valley height $\left(\mathrm{R}_{\mathrm{z}}\right)$. In this study, $\left(\mathrm{R}_{\mathrm{g}}\right)$ calculated from digital information from the surface of sample was used to evaluate the surface quality of the samples.

\section{Statistical design of experiment}

Central composite face-centered (CCFC) experimental statistical designs was used to optimize the experimental procedure. The sanding factors were first screened by ANOVA analysis and effective factors were determined by the response surface methodology (RSM). The experimental data were analyzed by multiple regression analysis through least square method. The regression coefficients of all terms including linear, quadratic and interaction. The model and their effect were analyzed by analysis of variance (ANOVA). All the terms of model were tested and verified statistically by F-test at probability levels $(\mathrm{p}<0,05)$. Adequacy of developed models was tested by performing $\left(\mathrm{R}^{2}\right)$, adjusted coefficient of $\left(\mathrm{R}^{2}\right.$-adj), normal probability plot (NPP) and residuals versus the fit the values. 3D surface plots were also used to determine the relationship between the independent variables and response. 
Finally, optimum values of machining parameters to achieve the minimum surface roughness were determined by using desirability function and lingo optimization solver.

\section{Response surface methodology (RSM)}

RSM developed by Box and Draper (1987) is a collection of mathematical and statistical techniques. Central composite design (CCD) is an experimental design used to achieve determine optimum process parameters for a minimal number of experiments. In this study, composite face-centered (CCFC) design was used to determine the optimal conditions for feed rate, cutting speed, grit size and depth of cut. Selection of independent variables and their ranges, experiments were established based on a CCFC design with four factors at five levels and each independent variable was coded at five levels between $(-2),(-1),(0),(1),(2)$. (Table 1) shows the number of parameters and their levels. The process parameters effects on performance around $\left(5^{4}\right) 625$ experiments are required, but using CCFC design 31 experiments are sufficient. (Table 2) shows the experimental parameters and their recoded roughness values.

Table 1. Sanding procedure parameters and levels.

\begin{tabular}{|c|c|c|c|c|c|c|c|}
\hline Symbol & Parameters & Unit & $\begin{array}{c}\text { Level } \\
(-1)\end{array}$ & $\begin{array}{c}\text { Level } \\
(-2)\end{array}$ & $\begin{array}{c}\text { Level } \\
(0)\end{array}$ & $\begin{array}{c}\text { Level } \\
(+1)\end{array}$ & $\begin{array}{c}\text { Level } \\
(+2)\end{array}$ \\
\hline $\mathrm{f}$ & Feed rate & $\mathrm{m} / \mathrm{min}$ & 2 & 6 & 10 & 14 & 18 \\
\hline $\mathrm{s}$ & Cutting speed & $\mathrm{m} / \mathrm{s}$ & 12 & 16 & 20 & 24 & 28 \\
\hline $\mathrm{d}$ & Depth of cut & $\mathrm{mm}$ & 1 & 3 & 5 & 7 & 9 \\
\hline $\mathrm{p}$ & Grit size & - & 100 & 120 & 150 & 180 & 220 \\
\hline
\end{tabular}

A second-order polynomial equation was used in order to develop an empirical model which correlated the responses independent variables. The general form second order polynomial equation is:

$$
Y=\beta_{0}+\sum_{i=1}^{k} \beta_{i} X_{i}+\sum_{i=1}^{k} \beta_{i i} X_{i}^{2}+\sum_{i} \sum_{j}^{k} \beta_{i j} X_{i} X_{j}+\epsilon
$$

According to equation (1) $\mathrm{Y}$ is the predicted reaction or reactions $\left(\mathrm{R}_{\mathrm{a}}\right), \mathrm{X}_{\mathrm{i}}$ and $\mathrm{X}_{\mathrm{j}}$ are variables, $\beta_{0}$ a constant, $\beta_{\mathrm{i}} \beta_{\mathrm{ij}}$ and $\beta_{\mathrm{ij}}$ are respectively the first, the second degree coded input parameters and parameter interactions of linear, quadratic and the second-order terms, respectively. Where $\mathrm{k}$ is the number of independent parameters ( $\mathrm{k}=4$ in this study) and $\epsilon$ is the error term. 
Table 2. Experimental parameters and the recorded roughness values.

\begin{tabular}{|c|c|c|c|c|c|}
\hline $\begin{array}{c}\text { Type of } \\
\text { test }\end{array}$ & Grit size & $\begin{array}{c}\text { Feed rate } \\
(\mathrm{m} / \mathrm{min})\end{array}$ & $\begin{array}{c}\text { Depth of cut } \\
(\mathrm{mm})\end{array}$ & $\begin{array}{c}\text { Cutting speed } \\
(\mathrm{m} / \mathrm{s})\end{array}$ & $\begin{array}{c}\text { Roughness } \\
\left(R_{a}, \mu \mathrm{m}\right) \\
\text { Pinus nigra }\end{array}$ \\
\hline 1 & 180 & 6 & 9 & 16 & 6,89 \\
\hline 2 & 150 & 10 & 5 & 20 & 7,16 \\
\hline 3 & 150 & 10 & 5 & 20 & 7,57 \\
\hline 4 & 120 & 14 & 9 & 16 & 9,04 \\
\hline 5 & 180 & 14 & 9 & 24 & 7,84 \\
\hline 6 & 180 & 6 & 1 & 16 & 8,37 \\
\hline 7 & 150 & 10 & 5 & 28 & 9,72 \\
\hline 8 & 120 & 14 & 1 & 16 & 7,97 \\
\hline 9 & 120 & 14 & 1 & 24 & 8,24 \\
\hline 10 & 120 & 14 & 9 & 24 & 9,31 \\
\hline 11 & 180 & 14 & 9 & 16 & 8,11 \\
\hline 12 & 150 & 2 & 5 & 20 & 8,51 \\
\hline 13 & 120 & 6 & 1 & 24 & 9,18 \\
\hline 14 & 150 & 10 & 5 & 20 & 8,12 \\
\hline 15 & 100 & 10 & 5 & 20 & 8,22 \\
\hline 16 & 150 & 18 & 5 & 20 & 8,91 \\
\hline 17 & 150 & 10 & 5 & 20 & 7,31 \\
\hline 18 & 120 & 6 & 9 & 24 & 8,78 \\
\hline 19 & 150 & 10 & 5 & 20 & 7,97 \\
\hline 20 & 150 & 10 & 3 & 20 & 7,16 \\
\hline 21 & 150 & 10 & 5 & 12 & 8,91 \\
\hline 22 & 150 & 10 & 7 & 24 & 7,31 \\
\hline 23 & 180 & 6 & 1 & 24 & 7,57 \\
\hline 24 & 220 & 10 & 5 & 20 & 7,14 \\
\hline 25 & 180 & 6 & 9 & 24 & 7,43 \\
\hline 26 & 150 & 10 & 5 & 20 & 7,69 \\
\hline 27 & 180 & 14 & 1 & 24 & 7,84 \\
\hline 28 & 180 & 14 & 1 & 16 & 8,24 \\
\hline 29 & 120 & 6 & 1 & 16 & 8,64 \\
\hline 30 & 120 & 6 & 9 & 16 & 8,91 \\
\hline 31 & 150 & 10 & 5 & 20 & 7,16 \\
\hline & & & 5 & & \\
\hline 2 & & 5 & 9 & & \\
\hline
\end{tabular}

\section{RESULTS AND DISCUSSION}

\section{Black pine samples}

The linear, linear-square, linear-interaction and second-order model equations have been fitted using Minitab software for $\mathrm{R}_{\mathrm{a}}$ response variable. The equations can be given in terms of the coded values of the in dependent variables as the following in (Table 3): 
Table 3. Regression models, $R^{2}$ and Adj- $R^{2}$ values.

\begin{tabular}{|l|l|l|}
\hline Regression model & $R^{2}$ & Adj- $R^{2}$ \\
\hline Linear & & \\
\hline$R_{a}(\mu \mathrm{m})=9,86-0,01408 \mathrm{p}+0,0169 \mathrm{f}+0,0048 \mathrm{~d}+0,0083 \mathrm{~s}$ & 26,57 & 15,27 \\
\hline Linear + square & & \\
\hline $\begin{array}{l}R_{a}(\mu \mathrm{m})=25,29-0,0523 \mathrm{p}-0,384 \mathrm{f}+0,052 \mathrm{~d} 1,122 \mathrm{~s}+0,000125 \mathrm{p}^{2}+0,02007 \mathrm{f}^{2}- \\
0,0051 \mathrm{~d}^{2}+0,02831 \mathrm{~s}^{2}\end{array}$ & 70,88 & 60,30 \\
\hline Linear + interaction & & \\
\hline $\begin{array}{l}R_{a}(\mu \mathrm{m})=8,25+0,0011 \mathrm{p}-0,247 \mathrm{f}+0,123 \mathrm{~d}+0,159 \mathrm{~s}+0,00142 \mathrm{pf}-0,00196 \mathrm{pd}- \\
0,00098 \mathrm{ps}+0,0147 \mathrm{fd}-0,0011 \mathrm{fs}+0,0015 \mathrm{ds}\end{array}$ & 41,25 & 11,87 \\
\hline Full quadratic & & \\
\hline $\begin{array}{l}R_{a}(\mu \mathrm{m})=23,73-0,0372 \mathrm{p}-0,649 \mathrm{f}+0,161 \mathrm{~d}-0,973 \mathrm{~s}+0,000126 \mathrm{p}^{2}+0,02009 \mathrm{f}^{2} \\
0,00509 \mathrm{~d}^{2}+0,02830 \mathrm{~s}^{2}+0,001417 \mathrm{pf}-0,001958 \mathrm{pd}-0,000979 \mathrm{ps}+0,01469 \mathrm{fd}-\end{array}$ & 85,60 & 74,1 \\
$0,00109 \mathrm{fs}+0,00189 \mathrm{ds}$ & & \\
\hline
\end{tabular}

(Table 4) displayed the ANOVA table for the second-order model proposed for $\mathrm{R}_{\mathrm{a}}$ given in suggested model. It is clear that the P-value is less than 0,05 showing the model is significant at $95 \%$ confidence level. This model shows that lack-of-fit error is insignificant indicating that the fitted model is accurate enough to predict the response. The model summary that R-square and Adj-R-square values were found as $85,6 \%$ and $74,1 \%$ respectively. The mathematical model was developed to determine the optimal values of the machining conditions leading to minimum value of $R_{a}$. A multilinear backforward elimination regression analysis was used to remove the non-significant factors in the models. The adequacy of the equations was performed by using $R$-square and $\operatorname{Adj}-R$-square values. $R$-square and Adj- $R$-square values were found as 81,96 and 77,23 respectively. Proposed mathematical model was presented in Eq. (2):

$$
\begin{aligned}
& R_{a}=23,18-0,01792 \times p-0,642 \times f+0,148 \times d-1,062 \times s+0,01871 \times f \times f+0,02681 \\
& 0,001417 \times p \times f-0,001958 \times p \times d+0,01469 \times f \times d
\end{aligned}
$$

Table 4. ANOVA for $\mathrm{R}_{\mathrm{a}}$ - Black pine.

\begin{tabular}{|l|l|l|l|l|}
\hline Source & DF & Adj SS & F-Value & P-Value \\
\hline Model & 9 & 13,7595 & 10,60 & 0,000 \\
\hline Linear & 4 & 10,3759 & 17,99 & 0,000 \\
\hline $\mathrm{p}$ & 1 & 2,7551 & 19,10 & 0,000 \\
\hline $\mathrm{f}$ & 1 & 0,4549 & 3,15 & 0,09 \\
\hline $\mathrm{d}$ & 1 & 0,8880 & 6,16 & 0,022 \\
\hline $\mathrm{s}$ & 1 & 4,8120 & 33,37 & 0,000 \\
\hline Square & 2 & 7,0695 & 24,51 & 0,000 \\
\hline $\mathrm{s}^{2}$ & 1 & 5,2286 & 36,26 & 0,000 \\
\hline $\mathrm{f}^{2}$ & 1 & 2,5980 & 18,02 & 0,000 \\
\hline 2 -Way Interaction & 3 & 2,2296 & 5,15 & 0,008 \\
\hline $\mathrm{f}^{*} \mathrm{~d}$ & 1 & 0,8836 & 6,13 & 0,021 \\
\hline $\mathrm{f}^{*} \mathrm{p}$ & 1 & 0,4624 & 3,21 & 0,008 \\
\hline $\mathrm{d}^{*} \mathrm{p}$ & 1 & 0,8836 & 6,13 & 0,022 \\
\hline Error & 21 & 3,0284 & & \\
\hline Lack-of-Fit & 15 & 2,1478 & 0,98 & 0,553 \\
\hline Pure Error & 6 & 0,8807 & & \\
\hline Total & 30 & 16,7879 & & \\
\hline
\end{tabular}

DF: degrees of freedom, SS: Sum of squares, F: F-test value and P:error variance a At a given response, parameters belonging to the filled cells are effective within $95 \%$ reliability interval. 


\section{Evaluation of the model}

Normality assumption is verified by applying the normal probability plot and histogram of residuals. From the Figure $1(\mathrm{a}, \mathrm{d})$, as the residuals generally fall on a straight line implying, the errors were resembled the normal distribution. Figures $1(b, c)$ shows the residuals falling in a horizontal band with no systematic pattern. As result of the residuals no unusual structure is apparent. This implies that the models proposed are adequate and there are no reason to suspect any violation of the independence or constant variance assumption.

(a)

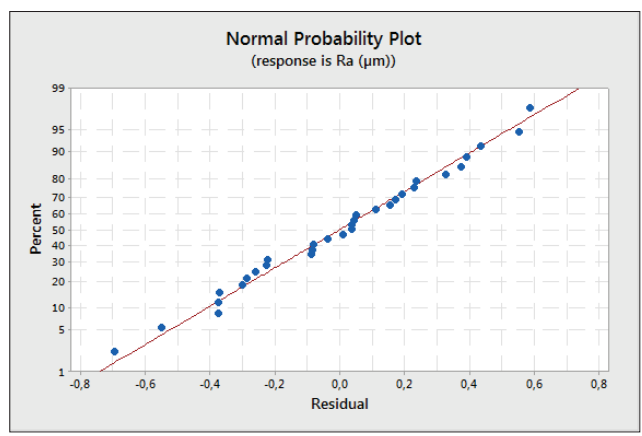

(c)

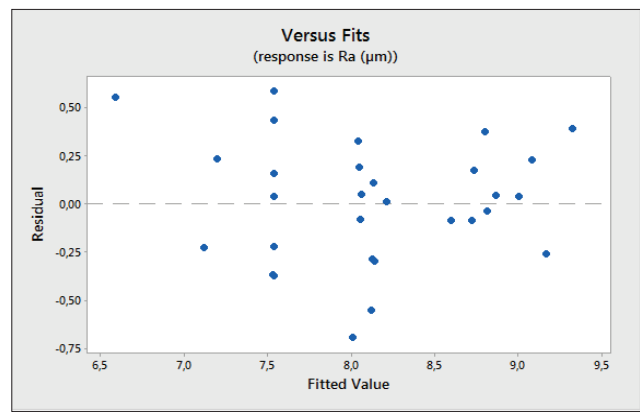

(b)

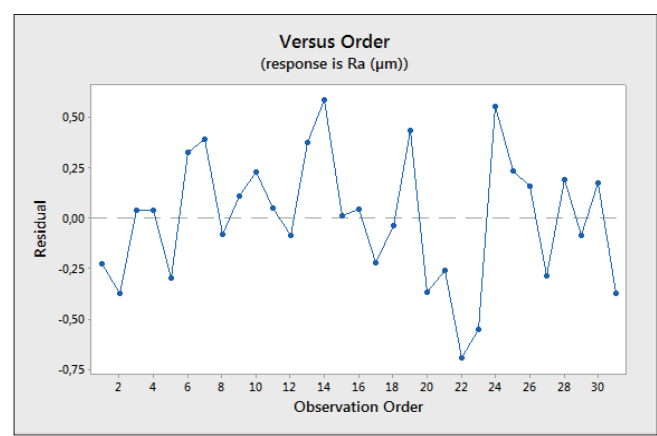

(d)

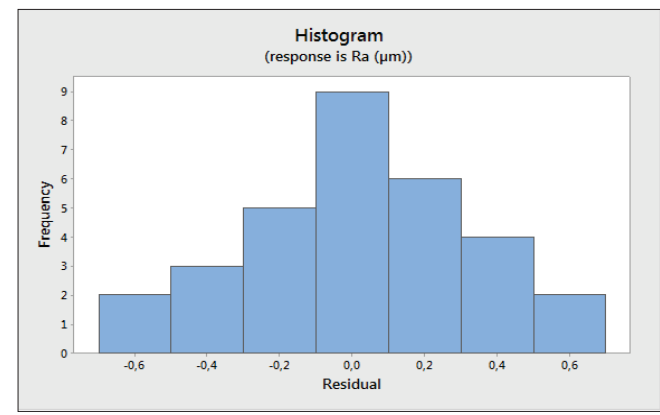

Figure 1. (a) Normal probability plot for standardized residuals (b) versus fits for standardize residuals (c) versus fits for standardize residuals (d) histogram of standardized residuals.

\section{Surface graphs and analysis of the results}

The interaction effect of process parameters on the surface roughness is discussed below.

(Figure 2a) shows the interaction plot between surface roughness and depth of cut with respect to grit size. From the figure, it can be seen that the grit size influencing on the effect on the surface roughness. As the grit size increases from 100 to 220, the surface roughness decreases. Moreover, it is found that the interaction effect between depth of cut and grit size played a significant role. The inference can also be verified from ANOVA as displayed in (Table 4). (Figure 2b) shows the interaction plot between surface roughness and feed rate with respect to grit size. From the figure, it can be seen that both feed rate and grit size are influencing on the effect of the surface roughness. As the grit size increase from 100 to 220, the surface roughness is increased Surface roughness was converged in all means from the maximum to a minimum value at the region of feed rate ranging from 5 to $10 \mathrm{~m} / \mathrm{min}$ and grit size from 200 to 220. (Figure 2c) shows the interaction plot between surface roughness and grit size with respect to cutting speed. Surface roughness was decreased at the region of cutting speed ranging from 15 to $21 \mathrm{~m} / \mathrm{min}$ and grit size from 200 to 220. (Figure 2d) shows the interaction plot between surface roughness and depth of cut with respect to cutting speed. According to the interaction 
plot, when the depth of cut was increased, the surface roughness was decreased. (Figure 3e) shows the interaction plot between surface roughness and feed rate with respect to depth of cut. It seems that both feed rate and depth of cut are influencing on the effect of the surface roughness. Also the lower feed rate had a greater influence on the surface roughness of the samples. If the depth of cut is increased, the surface roughness of the specimens also decreased. (Figure $2 \mathrm{f}$ ) shows the interaction plot between surface roughness and feed rate with respect to cutting speed. From the Figure $2 f$, the surface roughness was not influenced by the interaction between the feed rate and cutting speed.

(a)

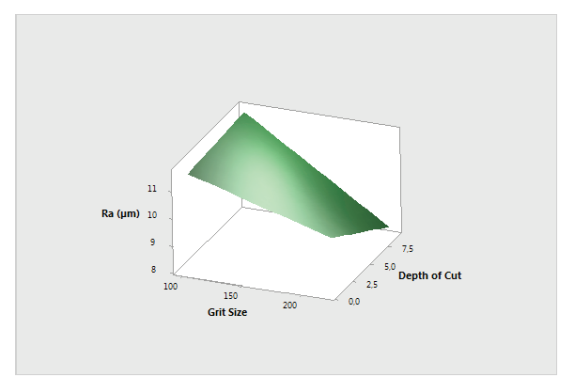

(c)

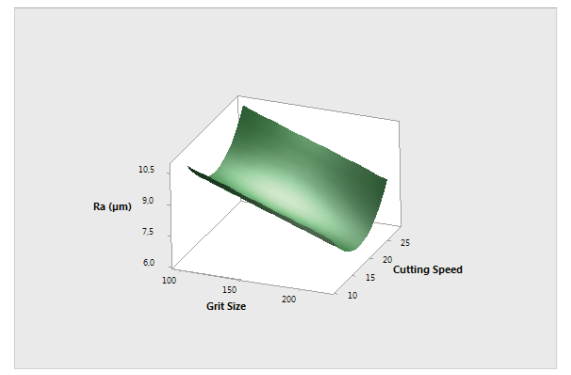

(e)

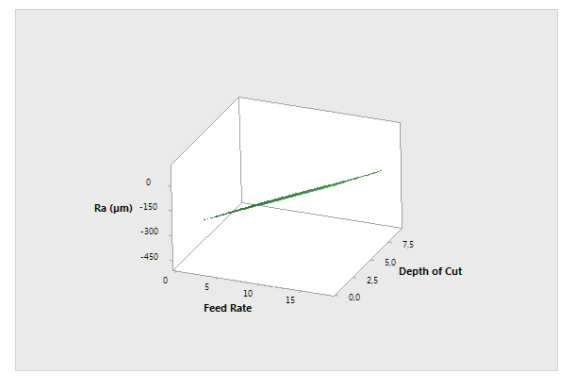

(b)

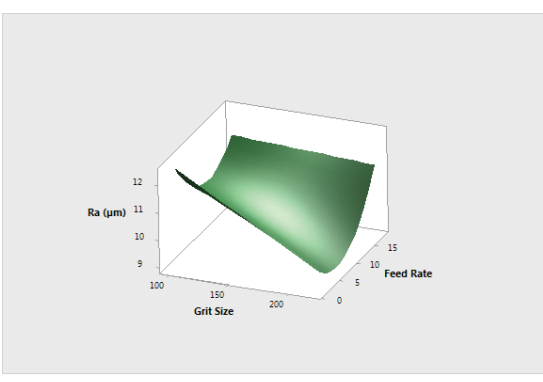

(d)

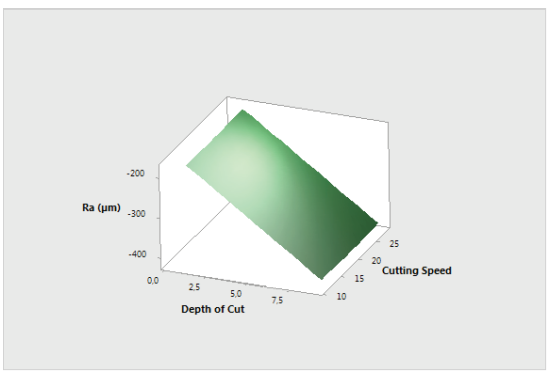

(f)

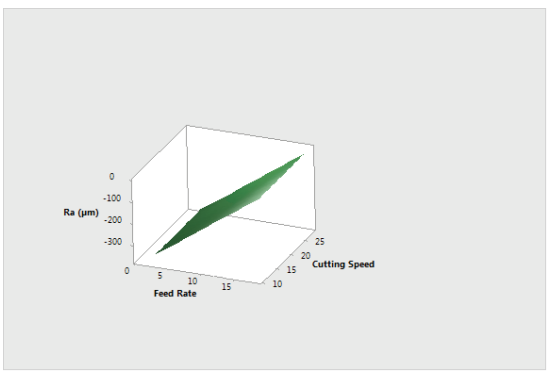

Figure 2. The response 3D surface plots of $R_{a}$ according to change feed rate, grit size, cutting speed and depth of cut.

\section{Parameter optimization}

The desirability function technique is one of the most widely used engineering applications for the parameter optimization. According to this function, the measured quality characteristics of every predicted response is transformed to a dimensionless desirability value. The value of the function is ranges between $d=0$ and $d=1$. The value of $d$ increase as the desirability of corresponding response increases. In this work, the transformation of wood surface roughness value is selected smaller-the-better quality characteristic. Therefore, selected equation was given in Eq. (3): 


$$
d_{i}=\left\{\begin{array}{lc}
1 & y_{i}<T \\
\left(\frac{U-y_{i}}{U-T}\right)^{\omega} & T \leq y_{i} \leq U \\
0 & y_{i}>U
\end{array}\right.
$$

Where $T$ symbolizes the target value of the $i$ th response, $y_{i}, L$ symbolizes the acceptable lower limit value, $U$ symbolizes the acceptable upper limit, for this response and $\omega$ represents the weight. From the analysis results shown in Figure 3 showed that the optimization value for $\left(\mathrm{R}_{\mathrm{a}}\right)$ was obtained as 5,634 $\mu \mathrm{m}$ using Minitab software.

Within ranges of processing parameters,

$$
2 \leq f \leq 18
$$

$$
100 \leq p \leq 220
$$

$$
1 \leq d \leq 9
$$

$$
12 \leq s \leq 28
$$

Optimal machining parameters for minimizing surface roughness was found with feed rate of 5,39 $\mathrm{m} / \mathrm{min}$, grit size of 100 , cutting speed of $19,75 \mathrm{~m} / \mathrm{s}$ and depth of cut of $9 \mathrm{~mm}$. Moreover, the desirability value 1,000 for surface roughness of specimens where also such value can be seen as close to 1 .

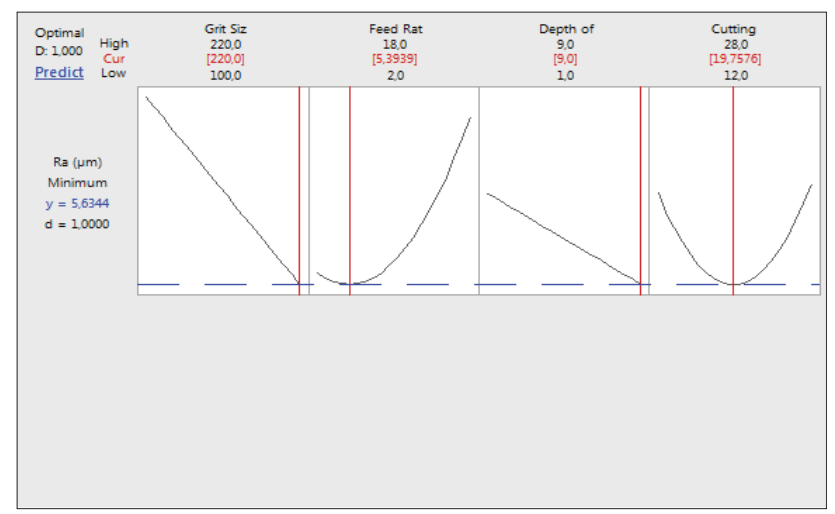

Figure 3. Response optimization plot for Black pine.

LINGO is a mathematical optimization modeling technique using linear and non-linear optimization problems. In this study, the experimental data was used to build a mathematical model such as linear, linear interaction, linear square and second order model. Selected mathematical model was optimized using Lingo solver to find the sanding conditions for minimizing the surface roughness. Feed rate, grit size, cutting speed and depth of cut values of 5,31 m/min, $220 \mathrm{p}, 19,80 \mathrm{~m} / \mathrm{s}$ and $9 \mathrm{~mm}$ were determined as global optimum sanding conditions resulting in minimum roughness 5,636 $\mu \mathrm{m}$ of Black pine samples. 


\section{Confirmation test}

The comparison of experimental results-predicted values is shown in (Table 5). Comparison results from evidence that predicted values for response value is close to experimentally obtained values. The mathematical models can be successfully used to predict the $R_{a}$ value for any combination of the feed rate, grit size, cutting speed and depth of cut within the range of the performed experimentation.

Table 5. Response optimization for surface roughness parameters -Black pine.

\begin{tabular}{|c|c|c|c|c|c|c|c|}
\hline Sr.no. & Feed Rate & $\begin{array}{c}\text { Cutting } \\
\text { Speed }\end{array}$ & $\begin{array}{c}\text { Depth } \\
\text { of cut }\end{array}$ & Grit size & $\begin{array}{c}\text { Experimental } \\
R_{a}\end{array}$ & RSM $R_{a}$ & Error (\%) \\
\hline 1 & 6 & 16 & 9 & 180 & 6,89 & 7,11 & 3,52 \\
\hline 2 & 10 & 20 & 5 & 150 & 7,16 & 7,53 & 1,5 \\
\hline 3 & 14 & 16 & 1 & 120 & 7,97 & 8,05 & 3,20 \\
\hline
\end{tabular}

\section{CONCLUSIONS}

For the surface roughness, mathematical models for Black pine were developed using response surface methodology to formulate the input parameters such as feed rate, grit size, cutting speed and depth of cut to the $\mathrm{R}_{\mathrm{a}}$. Selected mathematical models showed that the developed RSM models were statistically significant and suitable for all sanding conditions to have higher $\mathrm{R}^{2}$ and $\mathrm{R}^{2}$-adjusted values. High correlation values were determined between the experimental data and predicted ones. Feed rate, grit size, cutting speed and depth of cut values of 5,39 m/min, $220 \mathrm{P}, 19,75 \mathrm{~m} / \mathrm{s}$ and $9 \mathrm{~mm}$ were determined as optimum sanding conditions resulting in minimum roughness $5,634 \mu \mathrm{m}$ of Black pine samples. These results were verified with the Lingo optimization solver. The verification experiment was carried out to check the validity of the developed mathematical model that predicted surface roughness within the range of $6 \%$ error limit.

\section{REFERENCES}

Aslan, S.; Coşkun, H.; Kılıç, M. 2008. The Effect of the cutting direction, number of blades and grain size of the abrasives on surface roughness of Toros cedar. Building and Environment 43:696-701.

Box, G. E. P.; Draper, N. 1987. Empirical model-building and response surface. $1^{\text {st }}$ edn. John Wiley \& Sons, Inc., New York.

Carrano, A.L.; Taylor, J.B.; Lemaster, R. 2002. Parametric characterization of peripheral sanding. Forest Products Journal 52(9):44-50.

Gurau, L; Csiha, C; Mansfield-Williams, H. 2015.Processing roughness of sanded beech surfaces. European Journal of Wood and Wood Products 73:395-398.

Gurau, L.; Mansfield-Williams, H.; Irle, M. 2013.The influence of measuring resolution on the subsequent roughness parameters of sanded wood surfaces. European Journal of Wood and Wood Products 71(1):5-11.

Hernández, E.R.; Cool, J. 2008. Effects of cutting parameters on surface quality of paper birch wood machined across the grain with two planing techniques. Holz als Roh- und Werkstoff Journal 66(2):147-154. 
Herrrera, P.; Navarrete, J.; Werner, E. 2015. Adaptation of the tween 80 assay with a resolution v fractional factorial design and its application to rank Ophiostoma fungi with wood extractive degrading capabilitıes. Maderas. Ciencia y tecnología 17(1):85-98.

Hiziroglu, S; Zhong, Z.W.; Ong, W.K. 2014. Evaluation of bonding strength of pine, oak and nyatoh wood species related to their surface roughness. Measurement 49:397-400.

Hiziroglu, S; Zhong, Z.W.; Tang, H.L. 2013. Measurement of bonding strength of pine, kapur and meranti wood species as function of their quality. Measurement 46:3198-3201.

Jacob, S.; Banerjee, R. 2016. Modeling and optimization of anaerobic codigestion of potato waste and aquatic weed by response surface methodology and artificial neural network coupled genetic algorithm. Bioresource Technology 214:386-395.

Kılıç, M; Hiziroglu, S; Burdurlu, E. 2006. Effect of machining on surface roughness of wood. Building and environment 41:1074-1078.

Landry, V.; Blanchet, P. 2012. Surface preparation of wood for application of waterborne coatings. Forest Products Journal 62(2):39-45.

López, A.; Aisa, J.; Martinez, A.; Mercado, D. 2016. Injection moulding parameters influence on weight quality of complex parts by means of DOE application: Case study. Measurement 90:349-356. 790.

Magoss, E. 2015. Evaluating of the surface roughness of sanded wood. Wood Research 60(5):783-

Moura, L.F.; Hernandez, R.Z. 2006. Effects of abrasive mineral, grit size and feed speed on the quality of sanded surfaces of Sugar maple wood. Wood Science and Technology 40:517-530.

Ozdemir, T; Hiziroglu, S. 2007. Evaluation of some sanding factors on the surface roughness of particleboard. Silva Fennica 41:373-378.

Ratnasingman, J; Scholz, F. 2006. Optimal surface roughness for high-quality on Rubberwood. Holzals Roh-und Werkstoff 64:343-345.

Saloni, D.E.; Lemaster, R.L.; Jackson, S.D. 2010. Process monitoring evaluation and implementation for the wood abrasive machining process. Sensors 10(11):10401-10412.

Scrinzi, E.; Rossi, S; Deflorian, F; Zanella, C. 2011. Evaluation of aesthetic durability of waterborne polyurethane coatings applied on wood for interior applications. Progress in Organic Coatings 72(1):81-87.

Sulaiman, O; Hashim, R; Subari, K; Liang, C.K. 2009. Effect of sanding on surface roughness of rubberwood. Journal of Materials Processing Technology 209:3949-3955.

Tan, P.L.; Sharif, S; Sudin, I. 2012. Roughness models for sanded wood surfaces. Wood Sci Technol 46:129-142.

Vitosyte, J.J; Ukvalbergiene, K; Keturakis, G. 2012.The effect of surface roughness on adhesion strength of coated Ash (Fraxinus excelsior L.) and Birch (Betula L.) wood. Materials Science (Medziagotyra) 18(4):347-351.

Varanda, L.D.; Alves, M.C.S.; Gonçalves, M.T.T.; Santıago, L.F.F. 2010. Influência das variáveis no lixamento tubular na qualidade das peças de Eucalyptus grandis. Cerne Lavras 16:23-32. 